\title{
Silent Myocardial Infarction
}

National Cancer Institute

\section{Source}

National Cancer Institute. Silent Myocardial Infarction. NCI Thesaurus. Code C35400.

A history of myocardial infarction in the absence of clinical symptoms and positive electrocardiog raphic findings. 